\title{
Meningkatkan Kemampuan Berhitung Anak Usia 4-5 Tahun Melalui Media Lumbung Hitung
}

\author{
Elisa Malapata $^{1 凶}$, Lanny Wijayaningsih $^{2}$ \\ PG-PAUD, FKIP, Universitas Kristen Satya Wacana Salatiga
}

\begin{abstract}
This study to improve the numeracy skills of children aged 4 to 5 years through the media of granary counters in children in group A2 in TK Sinar Nyata Salatiga. This study uses classroom action research (CAR). This study consisted of two cycles and each cycle was held three times. The subjects of this study were 13 children, Group A2 in TK Sinar Nyata Salatiga. The technique of collecting data through observation and documentation. The results showed that there was an increase in numeracy skills in children aged 4 to 5 years through the media Lumbung Hitung. The learning process using the Lumbung Hitung media can improve the numeracy ability of children aged 4 to 5 years. Thus it can be concluded that through the media of the Lumbung Hitung can improve numeracy skills in children, group A2 in TK Sinar Nyata Salatiga.
\end{abstract}

Keywords: ability to count, media lumbung hitung

\begin{abstract}
Abstrak
Penelitian ini bertujuan untuk meningkatkan kemampuan berhitung anak usia 4-5 tahun melalui media lumbung hitung pada anak kelompok A2 di TK Sinar Nyata Salatiga. Penelitian ini merupakan penelitian tindakan kelas (PTK). Penelitian ini terdiri dari dua siklus dan setiap siklusnya dilaksanakan tiga kali pertemuan. Subjek penelitian ini adalah 13 anak Kelompok A2 TK Sinar Nyata Salatiga. Teknik pengumpulan data melalui observasi dan dokumentasi. Hasil penelitian menunjukan bahwa terdapat peningkatan kemampuan berhitung anak usia 4-5 tahun melalui media "Lumbung Hitung". Proses pembelajaran dengan menggunakan media Lumbung Hitung dapat meningkatkan kemampuan berhitung anak usia 4-5 tahun. Dengan demikian dapat disimpulkan bahwa melalui media Lumbung Hitung dapat meningkatkan kemampuan berhitung pada anak kelompok A2 di TK Sinar Nyata.
\end{abstract}

Kata kunci: kemampuan berhitung, media lumbung hitung

@ Jurnal Obsesi Prodi PG-PAUD FIP UPTT 2019

$\triangle$ Corresponding author :

Address : Salatiga Jawa Tengah

Email : 272015006@student.uksw.edu

ISSN 2356-1327 (Media Cetak)

ISSN 2549-8959 (Media Online) 


\section{PENDAHULUAN}

Pendidikan anak usia dini adalah pendidikan untuk membantu pertumbuhan dan perkembangan anak usia dini sesuai dengan karakteristik anak, sehingga anak dapat menjadi generasi penerus bagi bangsa Indonesia. Salah satu bentuk pendidikan anak usia dini yaitu taman kanak-kanak (Sri Handayani, 2014).

Kemampuan berhitung adalah salah satu pembelajaran yang diajarkan dalam pendidikan anak usia dini sebagai penentuan dalam jenjang Sekolah Dasar terutama pada anak usia 4-5 tahun yang berada pada kelompok A(Novianti, 2015). Pembelajaran berhitung juga merupakan bagian terpenting bagi anak, apabila kegiatan berhitung dilakukan dengan berbagai macam kegiatan dengan menggunakan media yang lebih menarik atau menggunakan permainan yang dapat mempengaruhi minat belajar dalam berhitung (Irawati, 2012).

Berdasarkan hasil pengamatan pada 13 anak di kelompok A2 TK Sinar Nyata, terdapat 8 anak yang masih sangat rendah dalam kemampuan berhitungnya. Pembelajaran berhitung dan pengenalan angka-angka masih diajarkan dari angka 15 dikarenakan anak masih di tahap awal masuk sekolah dan dalam tahap mengembangkan kemampuan berhitung. Namun, anak masih belum mempunyai kemampuan dalam berhitung dengan baik dan media yang digunakan dalam pembelajaran masih kurang mendukung berupa lembar kerja seperti menghubungkan gambar dengan angka, membuat gambar sebanyak angka, dan berhitung gambar sebanyak angka.

Dalam pemikiran anak usia 4-7 tahun adalah anak mampu mengelompokkan benda, mampu mengerjakan tugas yang berhubungan dengan himpunan benda dan angka. Konsep bilangan yang selalu berkaitan dengan pembelajaran dalam menghubungkan benda-benda dengan lambang bilangan (Wahyuni, Ali, \& ., 2016).

Berhitung merupakan kegiatan berhitung untuk anak usia dini yang disebut juga sebagai kegiatan menyebutkan urutan bilangan atau membilang buta. Anak menyebut urutan bilangan tanpa menyebutkan dengan benda-benda konkrit. Anak usia 4-5 tahun telah dapat menyebutkan urutan bilangan sampai sepuluh, sedangkan anak usia 5-6 tahun dapat menyebutkan bilangan sampai 1-20 atau lebih (Sriningsih dalam Nurwinda, 2011). Berhitung merupakan kegiatan yang dilakukan dalam rangka mengetahui jumlah atau banyaknya suatu benda. Berhitung juga merupakan kegiatan menghubungkan antara benda (korespondensi satu-satu) dengan konsep bilangan dimulai dari anga satu (Suyanto, 2005).

Pemahaman konsep bilangan terhadap anak perlu diberikan sejak dini dengan menggunakan cara yang mudah dimengerti oleh anak. hal ini berkaitan dengan adanya pendapat Sudaryanti menjelaskan bahwa konsep bilangan adalah salah satu konsep matematika yang penting untuk dikuasai oleh anak dalam setiap pembelajaran matematika (Reswita \& Wahyuni, 2018). Adapu menurut (Inra,2012:371) yang menyatakan bahwa konsep bilangan adalah ide atau dasar pengetahuan dalam memahami nilai banyak himpunan suatu benda dalam matematika(Sari, Putra, \& Kristiantari, 2016).

Kemampuan membilang merupakan salah satu kemampuan yang penting untuk anak dalam kehidupan sehari-hari, sehingga anak dapat membilang dengan baik. Anak juga perlu memahami angka dan konsep membilang. Membilang yaitu menyebutkan bilangan sesuai dengan 
urutan (Lestari kw, 2011:9). Adapun pernyataan Roy \& Edward (Dalam nunik Sulistiani, 2014:24) menjelaskan bahwa kemampuan membilang adalah kemampuan yang digunakan untuk menyatakan nomor berurutan dengan diawali dari "satu" dan menghubungkan setiap nomor pada satu dan hanya satu sehingga dapat membilang sesuatu yang konkrit atau nyata (Aprilianti, 2017).

Kata "media" berasal dari bahsa latin yaitu "medium" yang berarti "perantara atau pengantar". Media merupakan alat untuk menyampaikan atau menyalurkan pesan sebagai perantara dari pengirim atau penerima agar dapat menyampaikan suatu pembelajaran yang mudah dipahami oleh anak (Mudita, Suarni, \& Tirtayani, 2017). Media merupakan salah satu penyalur informasi atau penyampaian pesan sebagai alat pembelajaran yang dapat membantu guru dalam menyampaikan kegiatan pembelajaran kepada anak. (Cahyadi \& Hernita, 2018). Adapun media yang menciptakan pembelajaran menjadi lebih menarik, konkret dan nyata dalam kejelasan proses pembelajaran serta memanfaatkan media yang mudah dipahami dan aman untuk anak(rifana jita ridyawati, 2015).

Dalam penelitian ini, peneliti menggunakan media lumbung hitung untuk meningkatkan kemampuan berhitung anak. Media lumbung hitung hampir sama dengan congklak namun perbedaannya terletak pada bentuk. Jika congklak bentuknya mendatar namun media lumbung hitung ini berbentuk seperti tangga. Media lumbung hitung ini memiliki 10 kotak bulat yang disebut lumbung dan setiap lumbung memiliki perekat dimana perekat ini akan ditempelkan angka 1-10 dengan berbentuk seperti tangga. Media lumbung hitung ini digunakan dengan cara guru memberikan kartu angka 1-10 yang diacak dan anak akan mengurutkan angka 1-10 dengan merekatkannya ke lumbung tersebut, seperti anak merekatkan angka 1 ke lumbung satu, angka 2 merekatkan ke lumbung dua dan seterusnya sampai ke lumbung sepuluh, setelah anak mengurutkan angka dengan benar. Anak akan berhitung benda-benda tersebut ke dalam lumbung sesuai banyaknya angka yang diurutkan oleh anak.

Kelebihan dari lumbung hitung Selain itu, antara lain: 1) mudah didapatkan, 2) terbuat dari bahan yang aman untuk anak usia dini, 3) guru mendapat kesempatan untuk lebih mengenal anak, 4) anak dapat belajar tentang warna, dan 5) anak dapat belajar mengelompokan benda. Dalam penelitian ini menggunakan lumbung hitung yang dikatakan peneliti sebelumnya bahwa lumbung hitung ini sama dengan permainan congklak namun memiliki bentuk yang berbeda. Hal ini sama dengan penelitian yang dilakukan oleh Nuraidah Fitri Lubis yang menggunakan permainan congklak sebagai alat atau media untuk meningkatkan kemampuan berhitung anak (Lubis, 2017).

\section{METODOLOGI}

Metode penelitian yang digunakan adalah penelitian tindakan kelas. Penelitian dilakukan di TK Sinar Nyata pada kelompok Ayang berjumlah 13 anak, yang terdiri anak laki laki berjumlah 8 dan anak perempuan berjumlah 5. Penelitian ini dilakukan untuk mengetahui kemampuan berhitung anak melalui media lumbung hitung. Variabel dalam penelitian ini terdiri dari variabel terikat dan variabel bebas. variabel terikat adalah lumbung hitung dan variabel bebas adalah kemampuan berhitung . Prosedur atau rancangan penelitian ini memiliki tahap: 
286 The Problem Solving Skills in Kindergarten Student Based

(1) perencanaan; (2) tindakan; dan (3) pengumpulan data. Kemudian merancang kisi-kisi instumen pedoman penilaian.

Teknik analisis data yang dipakai dalam penelitian ini menggunakan instrumen pedoman penilaian untuk mengetahui kemampuan meningkatkan berhitung anak melalui media lumbung hitung maka penelitian ini menggunakan analisis data staistika deskriptif sederhana. Perhitungan yang digunakan dalam analisis data ini menghasilkan persentase pencapaian yang selanjutnya diinterprestasikan dengan kalimat.

$$
P=\frac{f}{N} x 100 \%
$$

$\mathrm{P}=$ Presentase

$\mathrm{F}=$ Nilai keseluruhan yang diperoleh anak

$\mathrm{N}=$ Skor maksimum dikalikan jumlah seluruh anak

\section{HASIL DAN PEMBAHASAN}

Penelitian tindakan kelas
dilakukan pada TK Sinar Nyata di Jl.
Imam Bonjol No. 2G, Salatiga. Lokasi
sekolah cukup strategis, karena berada
dekat dengan perumahan warga, tidak jauh
dari sekolah lain, dan sangat mudah
dijangkau karena tidak terlalu jauh dengan
jalan raya. TK Sinar Nyata Salatiga
mempunyai dua kelas yaitu TK A1 dan TK
A2. Penelitian dilakukan pada kelas TK
A2 yang berjumlah 13 anak, terdiri dari 8
laki-laki dan 5 perempuan. Sebelum
melaksanakan penelitian tindakan kelas
ini, peneliti terlebih dahulu melakukan
observasi untuk mengetahui perkembangan
kemampuan berhitung anak usia 4-5 tahun
pada saat proses pembelajaran calistung.

\section{Deskripsi Data Pra-Tindakan}

Sebelum melakukan penelitian tindakan kelas ini, peneliti melakukan observasi sebanyak tiga kali pada 29 Oktober 2018. Hal ini dilakukan agar peneliti mengetahui kemampuan berhitung dari kelompok A2 untuk melihat kondisi awal anak. Hasil yang akan diperoleh dari pengamatan ini dibandingkan dengan hasil nilai setelah melakukan tindakan. Dengan dilakukan perbandingan antara nilai yang sebelum dengan nilai setelah dilakukan tindakan maka akan dapat diketahui peningkatan yang terjadi dalam proses pembelajaran berhitung 1-10. Pembelajaran yang terjadi di TK Sinar Nyata sudah baik, namun dalam proses pembelajarannya masih kurang memanfaatkan media yang sudah ada di sekitar anak, sehingga pembelajaran kurang efektif dan kurang menarik minat anak dalam pembelajaran.

Pada 5 November 2018 peneliti memulai pembelajaran dengan mengajukan pertanyaan kepada anak siapa saja yang sudah bisa berhitung 1-10. Kemudian mengajak anak-anak berhitung 1-10. Ada beberapa anak yang ikut berhitung dan beberapa anak yang diam. Setelah anak-anak berhitung peneliti mengajarkan kepada anak untuk berhitung masih melalui cup, kartu angka dan manikmanik. Peneliti mengajarkan berhitung dengan cara kartu angka diacak, lalu anak memasangkan ke sepuluh cup, dimana didepan cup tersebut di letakkan atau di taruh angka 1-10, setelah anak menaruh angka 1-10, anak akan mulai berhitung sesuai angka yang diletakkan di depan cup. Cup ke satu ditaruh angka 1 jadi anak memasang manik-manik tersebut ke cup satu, cup kedua ditaruh angka 2 anak memasang manik-manik ke cup 2 dan sampai ke sepuluh cup anak memasangkan manik-manik ke cup 10 tersebut. Kemampuan berhitung anak yang telah 
dilakukan tersebut dapat dilakukan oleh 5 anak dari 13 anak di kelompok A2. Berikut ini adalah hasil dari refleksi awal yang digunakan sebagai data prasiklus :

\section{Tabel 3. Hasil Presentase Anak dengan} Presentase Keberhasilan Prasiklus

\begin{tabular}{|c|c|c|c|}
\hline \multirow[b]{2}{*}{ No } & \multirow{2}{*}{$\begin{array}{l}\text { Nama } \\
\text { Anak }\end{array}$} & \multicolumn{2}{|c|}{ Pra Tindakan } \\
\hline & & $\begin{array}{l}\text { Presentase } \\
\text { Pencapaian }\end{array}$ & $\begin{array}{c}\text { Status } \\
\text { Pencapaian }\end{array}$ \\
\hline 1 & $\mathrm{Aj}$ & $25 \%$ & $\mathrm{BM}$ \\
\hline 2 & Sab & $50 \%$ & MB \\
\hline 3 & $\mathrm{Zi}$ & $25 \%$ & BM \\
\hline 4 & $\mathrm{Da}$ & $50 \%$ & MB \\
\hline 5 & Sha & $100 \%$ & BSB \\
\hline 6 & Bri & $66 \%$ & $\mathrm{BSH}$ \\
\hline 7 & $\mathrm{Te}$ & $25 \%$ & $\mathrm{BM}$ \\
\hline 8 & Jo & $25 \%$ & $\mathrm{BM}$ \\
\hline 9 & $\mathrm{Ca}$ & $100 \%$ & $\mathrm{BSB}$ \\
\hline 10 & $\mathrm{Ri}$ & $100 \%$ & BSB \\
\hline 11 & Il & $41,6 \%$ & MB \\
\hline 12 & $\mathrm{Ar}$ & $25 \%$ & $\mathrm{BM}$ \\
\hline 13 & In & $41,6 \%$ & $\mathrm{MB}$ \\
\hline & Rata-rata & $52 \%$ & \\
\hline
\end{tabular}

Dari hasil tersebut diketahui bahwa daya tangkap anak terhadap pembelajaran kemampuan berhitung mencapai 52\% dari data yang sudah tercantum diatas bisa dikatakan bahwa status pencapaian untuk 13 anak tersebut belum tercapai dikarenakan masih berada dibawah ratarata $75 \%$. Peneliti terus mengamati setiap anak yang belum mampu berhitung 1-10 pada pembelajaran dan terus melatih anakanak dalam kemampuan berhitung.Hal ini disebabkan karena peneliti belum menggunakan alat peraga atau media pembelajaran yang peneliti buat sendiri.

\section{Tindakan Siklus I}

Tahap-tahap pada penelitian ini yaitu perencanaan, pelaksanaan, analisis dan refleksi. Tahap perencanaan tindakan pada siklus I pertemuan pertama mencakup: (1) rencana Program Pembelajaran Harian (RPPH); (2) mempersiapkan media pembelajaran yang digunakan untuk mendukung proses pembelajaran dengan media Lumbung Hitung menggunakan kartu angka 1-10, kacang-kacangan, (3) menyusun lembar observasi tentang kegiatan kemampuan berhitung anak usia 4-5 tahun melalui media Lumbung Hitung yang meliputi kisi-ksis penilaian yang meliputi anak mampu membilang banyak benda 1-10, anak mampu mengurutkan angka 1-10, dan anak mampu memasangkan benda 1-10.

Pertemuan pertama dilakukan pada 5 November 2018 dengan tema tumbuhan, subtema kacang-kacangan. Sebelum melakukan kegiatan pembelajaran peneliti terlebih dahulu menyapa anak-anak, mengajak anak-anak bernyanyi lagu umum "1,2,3,4,5,6,7,8" dan "Aku Anak TK". Setelah, peneliti mengajak anak bernyanyi. Kegiatan yang peneliti lakukan bersama anak-anak yaitu dengan menunjukkan alat peraga yang akan digunakan pada saat berhitung. Media yang peneliti gunakan pada saat pembelajaran yaitu lumbung hitung, kartu angka, kacang tanah.

Sebelum anak-anak memulai pembelajaran. Peneliti mengarahkan anakanak terlebih dahulu. Anak-anak antusias saat peneliti menunjukan media yang akan digunakan untuk berhitung. Peneliti menunjukkan kartu angka dan mengajak anak-anak berhitung bersama dari 1-10 dengan menggunakan kartu angka yang peneliti genggam anak-anak pun berhitung bersama meskipun masih ada yang diam dikarenakan belum bisa berhitung 1-10. Setelah berhitung, peneliti menunjukkan cara menggunakan lumbung hitung. Peneliti memasang angka 1 maka kacang diletakkan ke lumbung kesatu, jika angkanya 2 maka kacang diletakkan kedalam lumbung kedua, jika angka 3 maka kacang diletakkan kelumbung ketiga, jika angkanya 4 maka kacang diletakkan kedalam lumbung keempat, jika angka 5 
288 The Problem Solving Skills in Kindergarten Student Based

maka kacang diletakkan kedalam lumbung kelima, jika angka 6 maka kacang diletakkan kelumbung enam, jika angka 7 maka kacang diletakkan kedalam lumbung ketujuh, jika angka 8 maka diletakkan kedalam lumbung kedelapan, jika angka 9 maka diletakkan kedalam lumbung kesembilan, dan jika angka10 maka diletakkan kedalam lumbung kesepuluh. Setelah menjelaskan serta mempraktekkan kepada anak-anak cara berhitung dengan menggunakan lumbung hitung, peneliti mengajak satu orang anak untuk berhitung menggunakan lumbung hitung. Dan anak lainnya mengerjakan tugas yang telah guru kelas berikan. Kegiatan ini dilakukan peneliti dan satu anak, kegiatan ini dilakukan secara bergantian.

\section{Tabel 4. Hasil Presentase Anak dengan}

Presentase Keberhasilan Siklus I

\section{Pertemuan I}

\begin{tabular}{|c|l|l|c|}
\hline \multirow{2}{*}{ No } & \multirow{2}{*}{$\begin{array}{c}\text { Nama } \\
\text { Anak }\end{array}$} & \multicolumn{2}{c|}{ Pra Tindakan } \\
\cline { 3 - 4 } & & $\begin{array}{c}\text { Presentase } \\
\text { Pencapaian }\end{array}$ & $\begin{array}{c}\text { Status } \\
\text { Pencapaian }\end{array}$ \\
\hline 1 & $\mathrm{Aj}$ & $25 \%$ & $\mathrm{BM}$ \\
\hline 2 & $\mathrm{Sab}$ & $50 \%$ & $\mathrm{MB}$ \\
\hline 3 & $\mathrm{Zi}$ & $58,3 \%$ & $\mathrm{BSH}$ \\
\hline 4 & $\mathrm{Da}$ & $58,3 \%$ & $\mathrm{BSH}$ \\
\hline 5 & $\mathrm{Sha}$ & $25 \%$ & $\mathrm{BM}$ \\
\hline 6 & $\mathrm{Bri}$ & $66 \%$ & $\mathrm{BSH}$ \\
\hline 7 & $\mathrm{Te}$ & $58,3 \%$ & $\mathrm{BSH}$ \\
\hline 8 & $\mathrm{Jo}$ & $100 \%$ & $\mathrm{BSB}$ \\
\hline 9 & $\mathrm{Ca}$ & $100 \%$ & $\mathrm{BSB}$ \\
\hline 10 & $\mathrm{Ri}$ & $100 \%$ & $\mathrm{BSB}$ \\
\hline 11 & $\mathrm{Il}$ & $50 \%$ & $\mathrm{MB}$ \\
\hline 12 & $\mathrm{Ar}$ & $58,3 \%$ & $\mathrm{BSH}$ \\
\hline 13 & $\mathrm{In}$ & $50 \%$ & $\mathrm{MB}$ \\
\hline & Rata-rata & $\mathbf{6 2 \%}$ & \\
\hline
\end{tabular}

Berdasarkan hasil tindakan yang peneliti lakukan di siklus I pertemuan pertama persentase peningkatan kemampuan berhitung anak yang terjadi pada hasil tindakan siklus I, diperoleh hasil sebesar 62\%.Terjadinya peningkatan kemampuan berhitung anak pada refleksi pada pra siklus sejumlah $52 \%$ menjadi $62 \%$, namun belum mencapai target pencapaian $80 \%$.

Pertemuan kedua pada siklus I dilaksanakan pada 7 November 2018 dengan tema yang berbeda. Peneliti menggunakan tema lingkungan dengan subtema alat-alat didalam kelas (stik es krim). Kegiatan pembelajaran yang diawali dengan salam, doa dan menyanyi lagu umum "Bangun Tidur" dan "Yo Prokonco". Setelah itu peneliti mempersiapkan semua alat dan bahan untuk mendukung terlaksananya kegiatan berhitung dengan menggunakan Lumbung Hitung. Proses pembelajaran ini masih dilakukan antara peneliti dan satu anak untuk berhitung menggunakan lumbung hitung secara bergantian. Setelah satu anak selesai melakukan kegiatan berhitung, selanjutnya anak lain akan bergantian untuk berhitung. Untuk anak lain mengerjakan tugas yang guru kelasnya berikan sambil menunggu giliran berhitung. Hasil kemampuan Berhitung pada anak usia 4-5 Tahun di TK Sinar Nyata Salatiga sebagai berikut :

\section{Tabel 5. Hasil Presentase Anak dengan Presentase Keberhasilan Siklus I}

Pertemuan II

\begin{tabular}{|c|c|c|c|}
\hline \multirow[b]{2}{*}{ No } & \multirow{2}{*}{$\begin{array}{l}\text { Nama } \\
\text { Anak }\end{array}$} & \multicolumn{2}{|c|}{ Pra Tindakan } \\
\hline & & $\begin{array}{l}\text { Presentase } \\
\text { Pencapaian }\end{array}$ & $\begin{array}{c}\text { Status } \\
\text { Pencapaian }\end{array}$ \\
\hline 1 & $\mathrm{Aj}$ & $41,6 \%$ & $\mathrm{MB}$ \\
\hline 2 & $\mathrm{Sab}$ & $100 \%$ & BSB \\
\hline 3 & $\mathrm{Zi}$ & $50 \%$ & MB \\
\hline 4 & $\mathrm{Da}$ & $83 \%$ & BSB \\
\hline 5 & Sha & $100 \%$ & BSB \\
\hline 6 & Bri & $83 \%$ & BSB \\
\hline 7 & $\mathrm{Te}$ & $75 \%$ & $\mathrm{BSH}$ \\
\hline 8 & Jo & $100 \%$ & BSB \\
\hline 9 & $\mathrm{Ca}$ & $100 \%$ & BSB \\
\hline 10 & $\mathrm{Ri}$ & $100 \%$ & BSB \\
\hline 11 & Il & $50 \%$ & MB \\
\hline 12 & $\mathrm{Ar}$ & $91 \%$ & BSB \\
\hline 13 & In & $50 \%$ & MB \\
\hline \multicolumn{2}{|r|}{ Rata-rata } & $79 \%$ & \\
\hline
\end{tabular}


Berdasarkan hasil tindakan yang peneliti lakukan di siklus I pertemuan kedua tersebut, peneliti telah melakukan analisis terhadap pembelajaran kemampuan berhitung anak dengan menggunakan Lumbung Hitung tersebut. Peningkatatan yang terjadi pada hasil tindakan siklus I pertemuan kedua ini diperoleh hasil yang meningkat sebesar $79 \%$. Terjadinya peningkatan pada siklus I pertemuan satu yang diperoleh $62 \%$ menjadi $79 \%$.

Dari peningkatan persentase pencapaian anak diperoleh status pencapaian. 8 dari 13 dapat dikatakan bahwa penelitian pada siklus I pertemuan kedua meningkat namun belum mencapai target dari kriteria yang peneliti harapkan yaitu $80 \%$ maka dilanjutkan pada Siklus ke II.

\section{Tindakan Siklus II}

Pelaksanaan tindakan pada siklus II, peneliti melaksanakan hanya satu kali pertemuan dan peneliti telah mempersiapkan Rencana Program Pembelajaran Harian (RPPH) sebagai proses kegiatan pembelajaran kemampuan berhitung melalui media Lumbung Hitung. Peneliti menggunakan kembali tema yang sama dari pertemuan prasiklus yaitu tema Tumbuhan subtema kacang-kacangan (kacang tanah).

Pertemuan pada siklus II dilakukan pada 21 November 2018. Peneliti mempersiapkan media pembelajaran Lumbung Hitung untuk melakukan kegiatan berhitung. Sebelumnya peneliti memberi salam kepada anak-anak, berdoa, bernyanyi lagu umum anak. Setelah itu peneliti memerintahkan kepada anak untuk duduk ditempat duduknya masing-masing dengan mengerjakan tugas dari guru kelas, sedangkan peneliti dan satu anak melakukan kegiatan berhitung dengan menggunakan media Lumbung Hitung, anak lainnya akan bergantian. Anak-anak melakukan kegiatan berhitung dengan cara bergantian dikarenakan Lumbung Hitung ini hanya satu dan berukuran besar. Maka dari itu anak-anak akan bergantian berhitung, anak-anak lain yang belum berkesempatan berhitung, mengerjakan tugas dari guru kelas, seperti menggambar, menulis, membuat hasil karya.

Berdasarkan hasil dari peningkatan kemampuan berhitung anak usia 4-5 Tahun melalui media Lumbung Hitung pada pertemuan siklus II telah tercantum pada tabel dibawah ini:

Tabel 6. Hasil Presentase Anak dengan

Presentase Keberhasilan Siklus II

\begin{tabular}{|c|c|c|c|}
\hline \multirow{2}{*}{ No } & \multirow{2}{*}{$\begin{array}{l}\text { Nama } \\
\text { Anak }\end{array}$} & \multicolumn{2}{|c|}{ Pra Tindakan } \\
\hline & & $\begin{array}{l}\text { Presentase } \\
\text { Pencapaian }\end{array}$ & $\begin{array}{c}\text { Status } \\
\text { Pencapaian }\end{array}$ \\
\hline 1 & $\mathrm{Aj}$ & $50 \%$ & MB \\
\hline 2 & Sab & $100 \%$ & BSB \\
\hline 3 & $\mathrm{Zi}$ & $75 \%$ & $\mathrm{BSH}$ \\
\hline 4 & $\mathrm{Da}$ & $100 \%$ & BSB \\
\hline 5 & Sha & $100 \%$ & BSB \\
\hline 6 & Bri & $75 \%$ & $\mathrm{BSH}$ \\
\hline 7 & $\mathrm{Te}$ & $75 \%$ & $\mathrm{BSH}$ \\
\hline 8 & Jo & $100 \%$ & BSB \\
\hline 9 & $\mathrm{Ca}$ & $100 \%$ & BSB \\
\hline 10 & $\mathrm{Ri}$ & $100 \%$ & BSB \\
\hline 11 & Il & $66,6 \%$ & $\mathrm{BSH}$ \\
\hline 12 & $\mathrm{Ar}$ & $75 \%$ & $\mathrm{BSH}$ \\
\hline 13 & In & $66,6 \%$ & $\mathrm{BSH}$ \\
\hline \multicolumn{2}{|c|}{ Rata-rata } & $83 \%$ & \\
\hline
\end{tabular}

Berdasarkan tabel di atas dapat diketahui bahwa peningkatan kemampuan berhitung anak usia 4-5 tahun melalui media Lumbung Hitung menunjukkan ratarata pencapaian anak yang diperoleh $83 \%$. Dari hasil persentase pencapaian di atas membuktikan dalam penelitian ini dinyatakan berhasil meningkatkan kemampuan berhitung anak usia 4-5 tahun melalui media Lumbung Hitung dikarenakan dapat mencapai target pencapaian $80 \%$. Hal ini dapat disimpulkan bahwa dengan menggunakan 
290 | The Problem Solving Skills in Kindergarten Student Based

media Lumbung Hitung dapat meningkatkan kemampuan berhitung anak usia 4-5 dikelompok A2 TK Sinar Nyata Salatiga.

Berdasarkan analisis yang telah dilakukan peneliti dari prasiklus hingga siklus II dipengaruhi dengan adanya media yang diterapkan dalam pembelajaran berhitung melalui lumbung hitung. Lumbung hitung merupakan salah satu strategi pembelajaran yang tepat untuk anak usia dini karena anak mampu berhitung dengan mengenal bilangan 1-10, mengurutkan 1-10 dan menghubungkan atau memasangkan angka dengan benda 110. Kemampuan berhitung anak keseluruhan memiliki peningkatan yang sangat signifikan dan sudah mencapai keberhasilan yang telah ditetapkan dari target pencapaian. Hal ini juga mendukung anak untuk aktif ikut serta dalam pembelajaran. Melalui media lumbung hitung, pembelajaran tentang kemampuan berhitung mudah diserap anak oleh anak. Hasil pengamatan pada tindakan siklus II, tentang peningkatan kemampuan berhitung anak usia 4-5 tahun pada kelompok A2 melalui media Lumbung Hitung telah menunjukan bahwa hasil anak yang masuk kriteria telah mencapai $\geq 80 \%$, sehingga penelitian peningkatan kemampuan berhitung melalui Lumbung Hitung pada anak usia 4-5 tahun dihentikan. Sejalan yang dikatakan Arsyad (1996) bahwa pembelajaran merupakan media alat untuk menyampaikan atau menyalurkan pesan sebagai pesan pembelajaran atau media pembelajaran. Dengan adanya penggunaan media lumbung hitung ini anak banyak belajar dalam meningkatkan kemampuan berhitung. Kemampuan berhitung dapat meningkat sesuai indikator yang diberikan.

\section{Pembahasan}

$\begin{array}{clr}\begin{array}{c}\text { Dalam penelitian yang telah } \\ \text { dilakukan }\end{array} & \begin{array}{r}\text { menunjukkan } \\ \text { bahwa }\end{array}\end{array}$ kemampuan berhitung anak usia 4-5 tahun dapat meningkat dengan menggunakan media lumbung hitung. Dengan menggunakan lumbung hitung ini anak dapat berhitung dengan cara membilang angka 1-10, mengurutkan angka 1-10 dan memasangkan/menghubungkan benda 110. Seperti yang telah dijelaskan oleh peneliti sebelumnya bahwa dengan menggunakan media pohon hitung terbukti berhasil dan mampu meningkatkan kemampuan kognitif anak dalam mengurutkan bilangan 1-10. Dengan menggunakan media dalam proses pembelajaran berhitung berhasil dalam meningkatkan kemampuan berhitung anak (Erlina, 2018).

Dalam penelitian yang dilakukan peneliti tentang berhitung anak dengan media yang digunakan oleh peneliti yaitu lumbung hitung untuk membantu meningkatkan kemampuan berhitung anak megalami peningkatan. Hal ini sama dengan penelitian yang dilakukan oleh Nuraida Fitry Lubis yang mengatakan bahwa kemampuan berhitung anak memiliki peningkatan dengan menggunakan permainan congklak. Dalam menggunakan media pembelajaran dapat berpengaruh kepada kemampuan berhitung anak (Lubis, 2017).

Didalam penelitian yang dilakukan peneliti telah mendapatkan hasil dalam meningkatkan kemampuan berhitung anak maka dibutuhkan sebuah media pembelajran. Dalam penelitan ini, peneliti menggunakan media lumbung hitung untuk meningkatkan kemampuan berhitung anak usia dini. Hal tersebut sama dengan penelitian yang dilakukan oleh Nova Rozi yang mengatkan dalam penelitiannya menggunakan media papan telur melalui permainan berhitung dapat 
meningkatkan kecerdasan logika matematika. Dengan adanya media yang digunakan dalam pembelajaran dapat meningkatkan kemampuan berhitung (ROZI, 2007).

Dalam penelitian yang dilakukan peneliti telah dikatakan bahwa dengan media lumbung hitung anak dapat meningkatkan kemampuan berhitung. Dalam berhitung juga terdapat suasana yang menyenangkan dan tidak bosan dengan cara benda-benda yang digunakan dalam berhitung bisa diganti menggunakan benda-benda yang diminati anak. Hal ini serupa dengan penelitian sebelumnya yaitu permainan berhitung ceria dapat meningkatkan kemampuan berhitung dan keterampilan sosial. Didalam pembelajaran berhitung dapat menggunakan kegiatan bermain yang menjadikan anak senang sehingga tidak mudah bosan dengan pembelajaran tersebut (Perpustakaan UGM, 2000).

Penelitian yang dilakukan oleh peneliti yang berkaitan dengan media lumbung hitung dapat meningkatkan kemampuan berhitung anak, karena merupakan salah satu media pembelajaran matematika yang berupa operasi hitung. Hal ini serupa dengan penelitian sebelumnya yaitu pengenalan operasi hitung melalui permainan congklak dalam pembelajran matematika. Media pembelajaran juga dapat meningkatkan kemampuan operasi hitung pada anak (Siregar, Solfitri, \& Roza, 2018).

\section{KESIMPULAN}

Berhitung sangat penting dipelajari setiap anak. Oleh sebab itu tujuan dari penelitian yang telah peneliti lakukan apakah dengan menggunakan media lumbung hitung dapat meningkatkan kemampuan berhitung anak usia 4-5 tahun. Menggunakan media lumbung hitung ini dapat meningkatkan kemampuan berhitung anak. hal ini menunjukkan melalui table 1 sampai dengan tabel 2 menunjukkan adanya peningkatan berhitung pada anak. Dengan demikian, maka kemampuan berhitung anak dalam hal membilang, mengurutkan ataupun menghubungkan benda dengan angka meningkat melalui media lumbung hitung. Adapun saran yang diharapkan bahwa media lumbung hitung dapat digunakan sebagai salah satu media untuk meningkatkan kemampuan berhitung anak. Selain itu juga lumbung hitung dapat difungsikan sesuai dengan kebutuhan sekolah. Saran bagi peneliti untuk selanjutnya diharapkan dapat membuat rencana dan media yang lebih menarik lagi dan peneliti dapat menggunakan lumbung hitung dengan konsep yang berbeda.

\section{UCAPAN TERIMA KASIH}

Peneliti mengucapkan terima kasih kepada pihak sekolah yang telah senantiasa mengijinkan dan memberikan kesempatan kepada peneliti untuk melakukan penelitian.

\section{DAFTAR PUSTAKA}

Aprilianti, R. (2017). Meningkatkan Kemampuan Membilang Angka 1 Sampai 20 Melalui Permainan Bendera Pintar Pada Anak Usia 5-6 Tahun. Jurnal Golden Age Universitas Hamzanwadi, 02(4), 2233.

Cahyadi, F., \& Hernita, M. I. (2018). Peningkatan Keaktifan Dan Kemampuan Berhitung Melalui Media Puzzle Pada Anak. Paudia: Jurnal Penelitian Dalam Bidang Pendidikan Anak Usia Dini, 5(1). https://doi.org/10.26877/paudia.v5i1. 1177

Erlina, E. (2018). Meningkatkan Kemampuan Kognitif Mengurutkan 
292 The Problem Solving Skills in Kindergarten Student Based

Bilangan 1-10 Melalui Media Pohon Hitung Anak Kelompok B Di TK Baptis Setia Bakti Kota Kediri. PIJAR NUSANTARA, 3(2), 73. https://doi.org/10.29407/pn.v3i2.118 67

Irawati, R. M. (2012). Peningkatan Kemampuan Berhitung Anak Melalui Permainan Memancing Angka Di Taman Kanak- Kanak Sangrina Bunda Pasar Tiku. JURNAL ILMIAH PESONA PAUD, 1(3). Retrieved from http://ejournal.unp.ac.id/index.php/p aud/article/view/1658

Lubis, N. F. (2017). Peningkatan Kemampuan Berhitung Anak Usia 56 Tahun Melalui Permainan Congklak Di Tk Aisyiyah 19 Medan. Elementary School Journal Pgsd Fip Unimed, 5(2), 107-117. https://doi.org/10.24114/esjpgsd.v5i2 .4476

Mudita, komang eva, Suarni, ketut ni, \& Tirtayani, luh ayu. (2017). Penerapan Media Puzzle Gambar Untuk Meningkatkan Kecerdasan Logika Matematika Anak Kelompok B Di Paud Pradnya Paramita Singaraja. E-Journal Pendidikan Anak Usia Dini Universitas Pendidikan Ganesha Jurusan Pendidikan Guru Pendidikan Anak Usia Dini, 4(3).

Novianti, R. (2015). Pengembangan permainan roda putar untuk meningkatkan kemampuan berhitung angka anak usia 5-6 tahun. Jurnal Educhild, 4(1), 56-63.

Perpustakaan UGM, i-lib. (2000). Permainan "berhitung ceria" untuk meningkatkan kemampuan berhitung. Jurnal I-Lib UGM. Retrieved from http://ilib.ugm.ac.id/jurnal/download.php?d ataId $=834$

Reswita, R., \& Wahyuni, S. (2018). Efektivitas Media Pasir dalam Meningkatkan Kemampuan Konsep Bilangan pada Anak Usia 5-6 Tahun di Tk Aisyiyah Bengkalis. Lectura: Jurnal Pendidikan, 9(1), 43-51. https://doi.org/10.31849/lectura.v9i1. 927

rifana jita ridyawati. (2015). Peningkatan Keterampilan Menyimak Cerita Melalui Media VCD Film Kartun. Jurnal Pendidikan Guru Pendidikan Anak Usia Dini Edisi 5 Tahun Ke-4 2015. Retrieved from journal.student.uny.ac.id/ojs/index.p hp/pgpaud/article/download/327/299 $\mathrm{yu}$

ROZI, N. (2007). Peningkatan Kecerdasan Logika Matematika Anak Melalui Permainan Berhitung Menggunakan Papan Telur Di Tk Aisyiyah 7 Duri. Journal of Experimental Psychology: General, 136(1), 23-42.

Sari, D., Putra, A., \& Kristiantari, M. (2016). Penerapan Permainan Bola Gelinding (Boling) untuk Meningkatkan Kemampuan Mengenal Bilangan pada Anak Kelompok A. Pendidikan Anak Usia Dini, 4(2), 1-10.

Siregar, S. N., Solfitri, T., \& Roza, Y. (2018). Pengenalan Konsep Operasi Hitung Bilangan Melalui Permainan Congklak Dalam Pembelajaran Matematika. Al-Khwarizmi: Jurnal Pendidikan Matematika Dan Ilmu Pengetahuan Alam, 2(1), 119-128. https://doi.org/10.24256/jpmipa.v2i1. 107

Sri Handayani. (2014). Peningkatan Kemampuan Berhitung Anak Melalui Permainan Domino Di Taman Kanak-Kanak. Jurnal Pesona PAUD, 1(1), 1-12. Retrieved from http://download.portalgaruda.org/arti cle.php? article $=100825 \& \mathrm{val}=1492$

Wahyuni, S., Ali, M., \& . H. (2016). Peningkatan Kemampuan Berhitung Melalui Permainan Pohon Hitung Usia 4-5 Tahun Di TK. Jurnal Pendidikan Dan Pembelajaran, 5(7). Retrieved from http://jurnal.untan.ac.id/index.php/jp dpb/article/view/15828 
Tabel 1. Instrumen Penelitian

\begin{tabular}{|c|c|c|}
\hline Aspek & Indikator & Aktivitas \\
\hline \multirow[t]{4}{*}{ Kognitif } & \multirow{4}{*}{$\begin{array}{l}\text { Membilang } \\
\text { banyak benda } \\
1-10\end{array}$} & $\begin{array}{l}\text { Anak mampu membilang banyak } \\
\text { benda } 1-10 \text { memiliki skor } 4\end{array}$ \\
\hline & & $\begin{array}{l}\text { Anak mampu membilang banyak } \\
\text { benda } 1-7 \text { memiliki skor } 3\end{array}$ \\
\hline & & $\begin{array}{l}\text { Anak mampu membilang banyak } \\
\text { benda } 1-5 \text { memiliki skor } 2\end{array}$ \\
\hline & & $\begin{array}{l}\text { Anak mampu membilang banyak } \\
\text { benda } 1-10 \text { memiliki skor } 1\end{array}$ \\
\hline \multirow[t]{4}{*}{ Kognitif } & \multirow[t]{4}{*}{$\begin{array}{l}\text { Mengurutkan } \\
\text { angka1-10 }\end{array}$} & $\begin{array}{l}\text { Anak mampu mengururtkan angka } \\
1-10 \text { memiliki skor } 4\end{array}$ \\
\hline & & $\begin{array}{l}\text { Anak mampu mengururtkan angka } \\
1-77 \text { memiliki skor } 3\end{array}$ \\
\hline & & $\begin{array}{l}\text { Anak mampu mengururtkan angka } \\
1-5 \text { memiliki skor } 2\end{array}$ \\
\hline & & $\begin{array}{l}\text { Anak mampu mengururtkan angka } \\
1-3 \text { memiliki skor } 1\end{array}$ \\
\hline \multirow{4}{*}{$\begin{array}{l}\text { Kognitif/motorik } \\
\text { halus }\end{array}$} & \multirow{4}{*}{$\begin{array}{l}\text { Menghubung } \\
\text { kan/memsang } \\
\text { angka dengan } \\
\text { benda }\end{array}$} & Memasang 1-10 memiliki skor 4 \\
\hline & & Memasang 1-7 memiliki skor 3 \\
\hline & & Memasang 1-5 memiliki skor 2 \\
\hline & & Memasang 1-3 memiliki skor 1 \\
\hline
\end{tabular}

Kemampuan berhitung Anak usia 4-5 Tahun sebagai berikut :

Tabel 2 Kriteria Keberhasilan

\begin{tabular}{|c|c|}
\hline Kriteria & Pencapaian \\
\hline Berkembang sangat baik (BSB) & $76,00-100$ \\
\hline Berkembang sesuai harapan (BSH) & $51,00-75,00$ \\
\hline Mulai berkembang (MB) & $26,00-50,00$ \\
\hline Belum berkembang (BM) & $0,00-25,00$ \\
\hline
\end{tabular}

